\title{
The Impact of Inclusion Setting on the Academic Performance, Social Interaction and Self-Esteem of Deaf and Hard of Hearing Students: Systematic Review and Meta-Analysis
}

\author{
Sulaiman M. Alshutwi, Aznan Che Ahmad and Lay Wah Lee \\ School of Educational Studies, Universiti Sains Malaysia, Malaysia \\ https:/ / orcid.org/0000-0003-2604-4821 \\ https://orcid.org/0000-0003-1691-925X \\ https:// orcid.org/0000-0002-0684-7902
}

\begin{abstract}
This research investigates the impact of inclusion setting on academic performance, social interaction, and deaf and hard-of-hearing (D/HH) students' self-esteem. As opposed to the traditional nature of conducting a literature review, meta-analysis has the advantage of offering a critical evaluation of several previous studies with a common theme and combining their results. This has the potential of increasing statistical power which improves the generalizability of findings to a wider population. Thus, this study provides important conclusions that are likely to influence future research and decisions made by policymakers regarding the impact of inclusion setting on academic performance, social interaction and self-esteem of $\mathrm{D} / \mathrm{HH}$ students. Guidelines of PRISMA (2009) was adopted for searching relevant studies by using keywords. The websites of World Library World Cat, Cochrane Library, Web of Science, Biomed Central, Psyc INFO, Global Health, MEDLINE, EMBASE, PubMed, and Google Scholar were searched for relevant research conducted from January 1st, 1990 to February 28th, 2020. Therefore, the present study is a systematic review of the studies followed by a meta-analysis of proportions carried out using Med Calc online software. The results of the present findings have demonstrated that inclusion setting improves academic performance, social interaction, and self-esteem of $\mathrm{D} / \mathrm{HH}$ students. Based on our findings, we recommend that $\mathrm{D} / \mathrm{HH}$ children should have access to a 'good inclusion setting'. Therefore, policymakers and practitioners ought to advocate the need for developing special strategies for such children.
\end{abstract}

Keywords: Inclusion setting; Academic Performance; Social Interaction; Self-Esteem; Deaf and Hard of Hearing 


\section{Introduction}

\subsection{Background of the Study}

More than 5\% of the world's population suffers from D/HH (432 million adults and 34 million children). By 2050 there will be more than 900 million hearingimpaired (HI) people. That is to say, one out of every ten people shall suffer hearing impairment (WHO, 2020). The condition of hearing loss in adults whereby hearing loss exceeds $30-40$ decibels $(\mathrm{dB})$ is referred to as disabling hearing loss. 'Deaf' people have a hearing impairment and customarily communicate with the aid of sign language (WHO, 2020). Experts opined that the impact of hearing loss on children's educational achievements and development could be reduced if the disorder is detected early and timely intervention is applied. For instance, Callow-Heusser (2011) reported that early detection as well as management of hearing loss improves language and educational outcomes for $\mathrm{D} / \mathrm{HH}$ children. Evidence in literature identifies various effects of hearing loss. For example, functional, social, emotional, and economic are a few among the effects (National Research Council, 2004). A major effect of hearing impairments is evident in the ability of individuals while communicating with others. The spoken language development in children with unwanted hearing loss is often delayed. There are several detrimental effects concerning the inability of individuals to communicate causing a significant impact on their daily life such as experiencing feelings of loneliness.

The estimated value of about $\$ 750$ billion is believed to be the annual global cost of hearing loss according to the WHO (2020) report. These include costs of educational support, productivity reductions, social and health care (without the cost of hearing aids). D/HH children tend to have less self-esteem because of differences in the audience regarding social maturity, physical appearance, and communication skills. Since successful communication skills are not always coupled with excellent living standards, professionals, and clinicians working with $\mathrm{D} / \mathrm{HH}$ children need recognition, counseling, and external counselling for children in this population. As a result, it is critical to understand the components which contribute to self-esteem to improve communication skills (Warner-Czyz, Loy, Evans, Wetsel \& Tobey, 2015). D/HH children tend to display improved performance in literacy skills, ability to speak, and language development with appropriate intervention at an early stage. However, despite the aforementioned successes, several pupils continue to display disturbances in emotional, cognitive, and behavioural control, executive functioning, and self-regulation. Even though developmental learning is a complex process, it becomes necessary for educational settings to make available services that promote skill development in multiple dimensions, via ongoing assessment and revision. A model that involves articulated curriculum approaches for early intervention and special education programs can be considered and adopted in educating D/HH students (Mellon, Ouellette, Greer \& Gates-Ulanet, 2009).

The adoption of higher education policies in many developing countries is opening up higher education for $\mathrm{D} / \mathrm{HH}$ students. However, available data indicates that the participation of $\mathrm{D} / \mathrm{HH}$ students in higher education is low, and research indicates that allocation support is insufficient for those receiving benefits (Bell, Carl \& Swart, 2016). There is considerable research investigating 
social skills training and its effectiveness. However, there is a paucity of information about the impact of such training on deaf adolescents (Naeini, Arshadi, Hatamizadeh \& Bakhshi, 2013). Further, evidence in the study by Jaiyeola and Adeyemo (2018) demonstrates that D/HH students attending general education classes face difficulties in social skills and relationships and those consistent expectations of social outcomes include students' classroom communication and participation in extracurricular activities.

\subsection{Rationale of the Study}

Inclusive learning is a range of strategies that help students' learning, but some specific strategies can be used to teach a group that includes $\mathrm{D} / \mathrm{HH}$ students. Research suggests that deaf children may exhibit social difficulties in comparison with their listening contemporaries. Therefore, there is a need for a review of factors that influence these social interactions to design possible interventions (Batten, Oakes \& Alexander, 2014). A limited number of studies (e.g. Batten et al., 2014) have investigated the phenomenon, but they fall short to investigate the critical role of 'inclusion setting' on academic performance, social engagement, and students' self-esteem in $\mathrm{D} / \mathrm{HH}$. The present study makes use of systematic review and meta-analysis to unify those that have been done before. The outcome is likely to contribute to theory, practice, and policy.

\subsection{Objectives of the Study}

The following research questions guided the conduct of this study:

- What are the key themes in the selected studies involving inclusion setting as the independent variable and academic performance, social interaction, and self-esteem of deaf and hard-of-hearing students as the dependent variables?

- What is the effect size of the selected studies?

\section{Methodology}

\subsection{Data Sources}

Following the guidelines of PRISMA (2009), a comprehensive search of various studies around the world was conducted using five keyword search terms: "inclusion setting", "academic performance", "social engagement", "self-esteem" and "hearing loss". The websites that were searched for systematic reviews included World Library WorldCat, Cochrane Library, Web of Science, BiomedCentral, PsycINFO, Global Health, MEDLINE, EMBASE, PubMed, and Google scholar. Search dates were for studies carried out from January 1 ${ }^{\text {st }}, 1990$ to February $28^{\text {th }}, 2020$. This was followed by a meta-analysis using MedCalc online software.

\subsection{Inclusion criteria}

The study was limited to include settings $\mathrm{D} / \mathrm{HH}$ for students at any age only on their academic performance, social engagement, and self-esteem. This includes January 1, 1990, to February 28, 2020 (> more than 30 years). The major websites selected for systematic review and meta-analysis are Google, PubMed, Embase, Medline, Global Health, Psych Info, Biomed Central, Web of Science, Cochrane Library, World Library, and World Cat. 


\subsection{Exclusion criteria}

Studies that did not involve deaf or hard-of-hearing students were excluded, as well as those without the remaining keywords. Any study published outside the period January $1^{\text {st }} 1990$ and February $28^{\text {th }}, 2020$ did not qualify for inclusion.

\subsection{Systematic Review Strategy}

The Preferred Reporting Item for Systematic Review and Meta-Analysis (PRISMA) was used for the systematic review. PRISMA consists of a checklist and a diagram of a set of evidence-based topics that enables authors to conduct systematic reviews and meta-analyses (PRISMA, 2009). Figure 1 is a flow diagram showing the systematic review strategy following the PRISMA (2009) Guidelines.

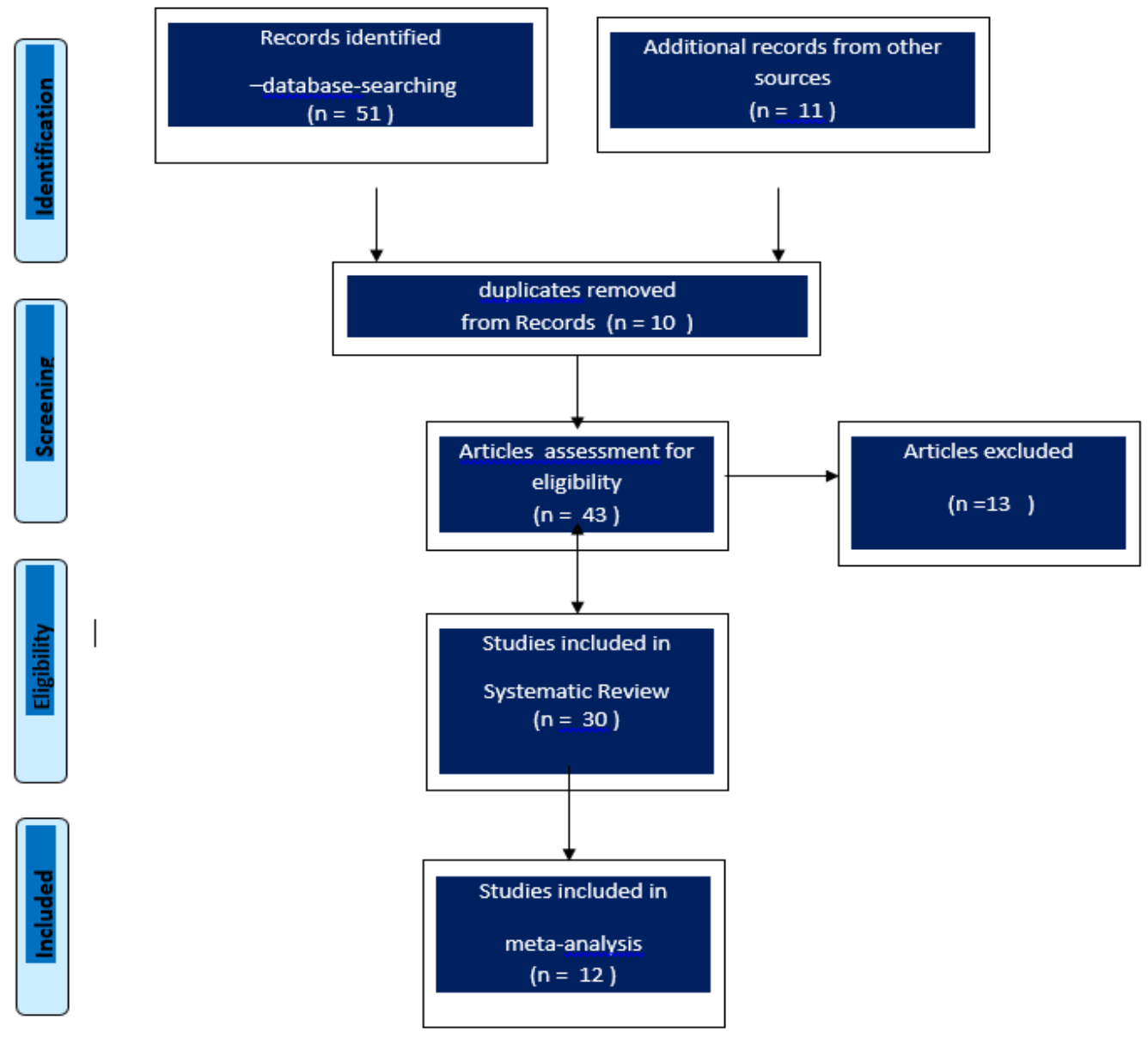

Figure 1: Systematic Review Strategy based on PRISMA (2009) Guidelines

\subsection{Meta-Analysis Strategy}

Arsenic square root transformation was used to calculate summary proportions weighted under fixed and random effects models according to the procedure described by Negeri, Shaikh \& Beyene (2018). The equation is embedded in MedCalc software. Approaches suggested by Campbell, Braspenning, Hutchinson and Marshall (2003) as well as Moher et al. (2015) were adopted in this study. The systematic review involved five steps; finding good evidence by visiting relevant sites, doing a search using keywords, digging deeper, reading 
the forest and funnel plots, and applying the evidence to address the research questions.

The forest plot served two purposes; [i] to determine the effect size and [ii] to assess the level of difference (or heterogeneity) among the different publications. The level of asymmetry in the funnel plot was used to establish the degree of publication bias. A study conducted by Sterne and Egger (2001) evaluated several possible measures for the vertical axis in funnel plots, found that the use of standard error was likely to be the best choice as it is easy to interpret. For this reason, the funnel plot was used to assess publication bias with standard error in the vertical axis and proportion in the horizontal axis.

\section{Study Findings}

The results of this study are presented in two sections: [i] systematic review and [ii] meta-analysis. These are presented below.

\subsection{Systematic Review}

Numerous studies have highlighted key elements for the success of inclusion settings on students such as (a) availability of the interdisciplinary intervention services in areas such as motor and cognitive development, psychosocial functioning, communication and language (Mason, Williams \& Cranmer, 2009), (b) the academic environment needs to motivate students to examine their hearing impairment in order to support them on the learning process. (Bell et al., 2016), attending regular schools, and having a well-spoken language high test score (Marschark, Shaver, Nagle \& Newman, 2015), (c) the total perceived ability score of adolescents with deafness and their ability to learn social skills (Soleimanieh, Arshadi, Hatamizadeh \& Soleimanieh, 2013), (d) The use of strategies to support communication, language, education and social/emotional development for their involvement (Borders, Bock, Giese, Gardiner-Walsh \& Probst, 2018).

The findings of a study by Theunissen, Netten, Briaire, Soede, Kouwenberg \& Frijns (2014) revealed that hearing-impaired children participating in mainstream education had better language skills $(\mathrm{t}=3.17, p<.001)$, higher intelligence scores $(\mathrm{t}=2.22, p<.001)$ and improved communication skills $(\mathrm{t}=-22.69, p<.001)$ as compared with children participating in special education. Like Chia-Fen (2013), there are a few authors who have highlighted issues on inclusion. Their findings suggest that $\mathrm{D} / \mathrm{HH}$ students experience less family stress despite low educational difficulties or a good GPA and family. Furthermore, contextually, the findings reveal the importance of relationships for assessing academic achievement and social competence between Taiwan's D/HH college students. The findings by Antia, Jones, Luckner, Kreimeyer \& Reed (2011) also revealed major positive effects of inclusion setting on disabled students and their teachers.

Some studies have highlighted new models of inclusion teaching for $\mathrm{D} / \mathrm{HH}$ students. For instance, Kathleen and McCain (2005) emphasize that D/HH students can achieve sustained academic progress over the years to include $\mathrm{D} / \mathrm{HH}$ students. Some studies have asserted that $\mathrm{D} / \mathrm{HH}$ children are associated with equal levels of attention, while children with specific hearing have emphasized domains of social participation and role function and engagement 
(Constantinescu-Sharpe, Phillips, Davis, Dornan \& Hogan, 2017). This study also found that the majority of child-friendly social inclusion outcomes were for those with normal hearing and good hearing. From the Master's Thesis study by Allison (2015) also appears that - teaching teachers about the opportunities for development in all students when disabled students are integrated at the high school level, is further required.

A review of the study by Dalton (2011) also highlighted the fact that how teachers can support autonomy, competence, and relatedness for students with MMHL. A study by Rachel (2012) revealed that inclusion classrooms generally promote desired behaviours and social skills and ESE inclusion practices are effective. Liversidge (2003) found that many factors can significantly help the students in their ability to decide to enroll and stay in a mainstream university such as level of commitment to attaining a college degree, past experience from the mainstream, ability to self-advocate, support systems and development of study skills. Davis (2004) observed that there is a need for a multi-method approach to teaching pupils with special educational needs. King and Ryan (2019) suggested that in a suitable physical and cultural environment, improvement in social interaction with their peers is possible.

The scientometric analysis is utilized to objectively map the scientific knowledge area while the critical review aims for the identification of the research themes as well as the resultant challenges based on the result of scientometric. Table 1 is a scientometric analysis of the eligible studies. The studies were published between 2005 and 2019. They included three surveys, two theses, one cohort pilot study, one longitudinal study, one qualitative study, two cross-sectional studies, two exploratory studies, one retrospective study, one quasi-experimental study, one evaluation case study, and one secondary analysis. The theme synthesis for the studies is presented in Table 2 .

Table 1: Scientometric Analysis of Eligible Studies in SR and MA (n=16).

\begin{tabular}{|c|l|c|c|c|}
\hline S/ N & \multicolumn{1}{|c|}{ Author(s) } & $\begin{array}{c}\text { Country of } \\
\text { Study }\end{array}$ & Year & Type of Study \\
\hline 1. & Ameye, et al. & Nigeria & 2015 & A cohort Pilot study \\
\hline 2. & Eriks-Brophy, A., \& Whittingham, J. & $\begin{array}{c}\text { Ottawa, } \\
\text { Canada }\end{array}$ & 2013 & Survey \\
\hline 3. & Mapolisa \& Tshabalala & Zimbabwe & 2013 & Qualitative study \\
\hline 4. & Alasim, K. N. & Saudi Arabia & 2018 & Exploratory Study \\
\hline 5. & Marschark et al. . & US & 2015 & Secondary Analysis \\
6. & Soleimanieh et al. & Iran & 2013 & Quasi-experimental \\
\hline 7. & Jaiyeola, M. T., \& Adeyemo, A. A. & 2018 & Cross-sectional study \\
\hline 8. & Chia-fen, L. & Taiwan & 2013 & Thesis \\
\hline 9. & Antia et al. & UK & 2011 & Longitudinal study \\
10. & Prakash, S. S. & Slovenia & 2012 & Survey \\
\hline 11. & Schmidt, M., \& Čagran, B. & US & 2008 & Evaluation case study \\
\hline 12. & Kathleen, G., \& McCain, S. A. & Netherlands & 2014 & $\begin{array}{c}\text { Retrospective, } \\
\text { multicenter study }\end{array}$ \\
\hline 13. & Theunissen et al. & & & \\
\hline
\end{tabular}




\begin{tabular}{|c|c|c|c|c|}
\hline 14. & $\begin{array}{l}\text { Alegre de la Rosa, O. M. A., \& } \\
\text { Angulo, L. M. V. }\end{array}$ & Spain & 2019 & $\begin{array}{l}\text { Exploratory factor } \\
\text { analysis }\end{array}$ \\
\hline 15. & Constantinescu-Sharpe et al. & Australia & 2017 & Survey \\
\hline 16. & Rachel, E. & US & 2012 & Thesis \\
\hline
\end{tabular}

Table 2: Theme synthesis in the systematic review

\begin{tabular}{|c|c|c|c|c|c|}
\hline $\mathrm{S} / \mathrm{N}$ & Author(s) & $\begin{array}{l}\text { Study } \\
\text { methodology }\end{array}$ & Key findings & $\begin{array}{l}\text { Implications of the } \\
\text { studies }\end{array}$ & $\begin{array}{l}\text { Key themes } \\
\text { synthesized from the } \\
\text { studies }\end{array}$ \\
\hline 1. & $\begin{array}{l}\text { Ameye, et al. } \\
(2015) .\end{array}$ & $\begin{array}{l}\text { A cohort pilot } \\
\text { study involving } \\
\text { deaf students in } \\
\text { special education } \\
\text { secondary schools } \\
(\mathrm{n}=50)\end{array}$ & $\begin{array}{l}\text { - A significant percentage } \\
\text { of the students had a } \\
\text { limitation in achievement. } \\
\text { - More than } 33 \% \text { of the } \\
\text { students were denied } \\
\text { privileges as a result of being } \\
\text { deaf. } \\
\text { - A significant percentage } \\
\text { of the students were not } \\
\text { satisfied with the placement. }\end{array}$ & $\begin{array}{l}\text { Economic and } \\
\text { educational policies } \\
\text { need sensitization }\end{array}$ & $\begin{array}{l}\text { Minor impact of } \\
\text { inclusion } \\
\text { of deaf children }\end{array}$ \\
\hline 2. & $\begin{array}{l}\text { Eriks-Brophy, } \\
\text { A. \& } \\
\text { Whittingha, J. } \\
\text { (2013). }\end{array}$ & \begin{tabular}{|l|}
63 classroom \\
teachers involved \\
in the study to \\
determine whether \\
teachers had the \\
right attitudes, \\
knowledge, and \\
teaching skills
\end{tabular} & $\begin{array}{l}\text { The teachers had favorable } \\
\text { attitudes, knowledge and } \\
\text { teaching skills for students } \\
\text { with hearing loss }\end{array}$ & $\begin{array}{l}\text { For inclusion to } \\
\text { succeed, teacher } \\
\text { education programs } \\
\text { should: } \\
\text { - Emphasize more } \\
\text { on the needs of } \\
\text { learners with hearing } \\
\text { impairment } \\
\text { - Provide requisite } \\
\text { support for both } \\
\text { students and } \\
\text { teachers. }\end{array}$ & $\begin{array}{l}\text { Minor impact of } \\
\text { inclusion } \\
\text { of children } \\
\text { with hearing loss }\end{array}$ \\
\hline 3. & $\begin{array}{l}\text { Mapolisa \& } \\
\text { Tshabalala } \\
(2013) .\end{array}$ & $\begin{array}{l}\text { Qualitative Inquiry } \\
\text { of teachers' } \\
\text { experience in } \\
\text { handling hearing } \\
\text { impairment among } \\
\text { children } \\
n=50 \text { teachers } \\
\text { using purposive } \\
\text { sampling. }\end{array}$ & $\begin{array}{l}\text { The study found that: } \\
\text { - Hearing impaired } \\
\text { children in ordinary schools } \\
\text { had various problems. } \\
\text { - Majority of the regular } \\
\text { teachers were lacking } \\
\text { adequate resources and the } \\
\text { necessary expertise. }\end{array}$ & $\begin{array}{l}\text { Regular teachers } \\
\text { should: } \\
\text { - Undergo in- } \\
\text { service training } \\
\text { - } \quad \text { Be provided with } \\
\text { proper equipment for } \\
\text { effective teaching } \\
\text { children with hearing } \\
\text { impairment }\end{array}$ & $\begin{array}{l}\text { - Inclusion is } \\
\text { important for hearing } \\
\text { impairment children } \\
\text { - The provision of } \\
\text { equipment for effective } \\
\text { teaching of children } \\
\text { with hearing } \\
\text { impairment is a } \\
\text { necessity. } \\
\text { inclusion setting } \\
\text { inclumor impact of }\end{array}$ \\
\hline 4. & $\begin{array}{l}\text { Alasim, K. N. } \\
(2018)\end{array}$ & $\begin{array}{l}\text { The study was to } \\
\text { identify strategies } \\
\text { that facilitate } \\
\text { participation and } \\
\text { interaction of Deaf } \\
\text { and hard of } \\
\text { hearing students. }\end{array}$ & $\begin{array}{l}\text { The study found that DHH } \\
\text { students face barriers to } \\
\text { participation and interaction } \\
\text { in the general education } \\
\text { classroom. }\end{array}$ & $\begin{array}{l}\text { There is a need for } \\
\text { specific strategies to } \\
\text { facilitate the } \\
\text { participation of } \\
\text { d/Deaf and hard of } \\
\text { hearing students }\end{array}$ & $\begin{array}{l}\text { Minor impact of } \\
\text { inclusion setting } \\
\text { Inclusion improves the } \\
\text { participation of Deaf } \\
\text { and hard-of-hearing } \\
\text { students }\end{array}$ \\
\hline 5. & $\begin{array}{l}\text { Marschark et al. } \\
(2015) \text {. }\end{array}$ & $\begin{array}{l}\text { The study involved } \\
\text { analysis of data } \\
\text { from the National } \\
\text { Longitudinal } \\
\text { Transition Study-2 } \\
\text { (NLTS2), funded } \\
\text { by the U.S } \\
(\mathrm{n}=11,000)\end{array}$ & $\begin{array}{l}\text { Findings indicated that } \\
\text { teachers can appropriately } \\
\text { target their instruction by } \\
\text { recognizing the diverse } \\
\text { strengths and needs of } \\
\text { hearing impaired students }\end{array}$ & $\begin{array}{l}\text { Teachers need to } \\
\text { develop quality } \\
\text { instructional } \\
\text { approaches that take } \\
\text { into account the } \\
\text { diverse needs of } \\
\text { hearing impaired } \\
\text { students }\end{array}$ & $\begin{array}{l}\text { - Instructional } \\
\text { quality impacts } \\
\text { positively on the } \\
\text { performance of } \\
\text { children with hearing } \\
\text { loss } \\
\text { inclusion setting }\end{array}$ \\
\hline
\end{tabular}




\begin{tabular}{|c|c|c|c|c|c|}
\hline 6. & $\begin{array}{l}\text { Soleimanieh et } \\
\text { al. (2013). }\end{array}$ & $\begin{array}{l}\text { This was a pre-post } \\
\text { quasi-experimental } \\
\text { design involving } \\
\text { female students } \\
\text { with deafness } \\
(\mathrm{n}=69)\end{array}$ & $\begin{array}{l}\text { There was significant } \\
\text { improvement in total } \\
\text { perceived competence scores } \\
\text { of adolescents with deafness } \\
\text { due to intervention }(\mathrm{P}< \\
0.001) \text { in addition to three } \\
\text { domains of socio-emotional } \\
\text { competence }(\mathrm{P}=0.003) \\
\text { school adjustment }(\mathrm{P}=0.018) \\
\text { and communication } \\
\text { competence }(\mathrm{P}<0.001) \text {. }\end{array}$ & $\begin{array}{l}\text { Improvement in the } \\
\text { adolescents' sense of } \\
\text { competence and } \\
\text { emotional wellbeing } \\
\text { through learning } \\
\text { social skills. }\end{array}$ & \begin{tabular}{|l|}
$\quad$ Social skills among \\
adolescent students \\
with deafness impacts \\
positively on their \\
emotional and \\
communication \\
competence \\
- Major impact of \\
inclusion setting
\end{tabular} \\
\hline 7. & $\begin{array}{l}\text { Jaiyeola, M. T. } \\
\text { \& Adeyemo, } \\
\text { A.A. (2018). }\end{array}$ & $\begin{array}{l}\text { The study } \\
\text { investigates the } \\
\text { quality of life of } \\
\text { DHH students in } \\
\text { Ibadan, Nigeria } \\
\text { using a cross- } \\
\text { sectional study. } \\
(n=110)\end{array}$ & $\begin{array}{l}\text { The study found that the } \\
\text { majority of deaf and hard of } \\
\text { hearing students }(57.8 \%) \text { had } \\
\text { poor quality of life. }\end{array}$ & $\begin{array}{l}\text { Factors influencing } \\
\text { the quality of life for } \\
\text { DHH students } \\
\text { should be attended } \\
\text { to. }\end{array}$ & $\begin{array}{l}\text { Poor quality of life } \\
\text { for Deaf and hard-of- } \\
\text { hearing students may } \\
\text { affect their academic } \\
\text { achievement. } \\
\text { inclusion setting }\end{array}$ \\
\hline 8. & $\begin{array}{l}\text { Chia-fen, L. } \\
(2013) .\end{array}$ & $\begin{array}{l}\text { The thesis } \\
\text { objective was to } \\
\text { identify the factors } \\
\text { influencing the } \\
\text { academic and } \\
\text { social adjustment } \\
\text { of college students } \\
\text { with hearing loss } \\
\text { in Taiwan }\end{array}$ & $\begin{array}{l}\text { The study found that } \\
\text { students with hearing loss } \\
\text { experienced less family stress } \\
\text { and had fewer academic } \\
\text { difficulties leading to better } \\
\text { GPAs. Als, the family } \\
\text { relationship was altogether } \\
\text { related with academic } \\
\text { achievement. }\end{array}$ & $\begin{array}{l}\text { In the university level } \\
\text { have to develop a } \\
\text { helpful program and } \\
\text { an encouraging } \\
\text { environment for } \\
\text { DHH undergraduate } \\
\text { students in Taiwan. }\end{array}$ & $\begin{array}{l}\text { Academic achievement } \\
\text { and social aspect of } \\
\text { DHH students' } \\
\text { remains obscure in } \\
\text { Taiwan. }\end{array}$ \\
\hline 9. & $\begin{array}{l}\text { Antia et al. } \\
(2011) .\end{array}$ & $\begin{array}{l}\text { This was a 5-year } \\
\text { longitudinal study } \\
\text { that examined the } \\
\text { social skills and } \\
\text { problem } \\
\text { behaviours of } \\
\text { D/HH students }\end{array}$ & $\begin{array}{l}\text { The study found that some } \\
\text { students placed in inclusive } \\
\text { settings did not realize } \\
\text { positive outcomes. }\end{array}$ & $\begin{array}{l}\text { The impact of } \\
\text { inclusion on } \\
\text { important outcomes } \\
\text { needs more research } \\
\text { attention. }\end{array}$ & $\begin{array}{l}\text { - Greater focus on } \\
\text { the characteristics of } \\
\text { effective instruction in } \\
\text { inclusion settings is a } \\
\text { necessity. } \\
\text { - Major impact of } \\
\text { inclusion setting }\end{array}$ \\
\hline 10. & $\begin{array}{l}\text { Prakash, S.S. } \\
(2012)\end{array}$ & This was a survey & $\begin{array}{l}\text { Most teachers were for } \\
\text { the inclusion of students } \\
\text { with disabilities. } \\
\text { There were significant } \\
\text { differences in teachers' } \\
\text { attitudes towards inclusion } \\
\text { across their qualification, } \\
\text { management level, level of } \\
\text { teaching, gender and } \\
\text { teaching experience. }\end{array}$ & $\begin{array}{l}\text { Interventional needs } \\
\text { to bring out teachers' } \\
\text { more positive } \\
\text { attitudes. }\end{array}$ & \begin{tabular}{|l|}
$\quad$ Major positive \\
impact of inclusion of \\
children with hearing \\
loss. \\
- Teachers' attitudes \\
towards inclusion \\
varies across \\
qualification, \\
experience, gender, \\
level of teaching and \\
management level.
\end{tabular} \\
\hline 11. & $\begin{array}{l}\text { Schmidt, M. \& } \\
\text { Čagran, B. } \\
\text { (2008). }\end{array}$ & $\begin{array}{l}\text { This was an } \\
\text { evaluation case } \\
\text { study that } \\
\text { investigated the- } \\
\text { self-concept of } \\
\text { students from } 7 \text { th } \\
\text { grade in regular } \\
\text { primary schools. }\end{array}$ & $\begin{array}{l}\text { Integrated students with } \\
\text { hearing impairment in } \\
\text { regular classrooms } \\
\text { performed below their } \\
\text { hearing counterparts in } \\
\text { academics and social self- } \\
\text { concept } \\
\text { There was a noticeable } \\
\text { advantage for the students } \\
\text { from the class with } \\
\text { integrated learners over the } \\
\text { other class serving as } \\
\text { control group }\end{array}$ & $\begin{array}{l}\text { Students with } \\
\text { hearing impairment } \\
\text { need adequate } \\
\text { support }\end{array}$ & 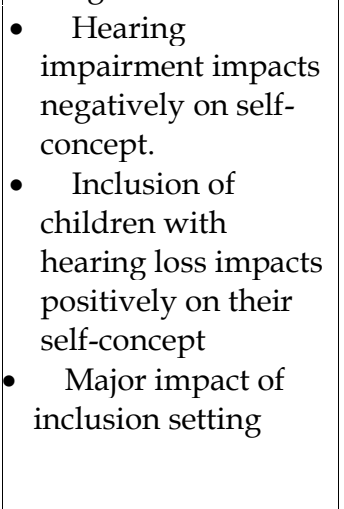 \\
\hline
\end{tabular}




\begin{tabular}{|c|c|c|c|c|c|}
\hline 12. & $\begin{array}{l}\text { Kathleen, G. \& } \\
\text { McCain, S. A. } \\
\text { (2005). }\end{array}$ & \begin{tabular}{|l|} 
The study involved \\
communication \\
participation, \\
academic \\
achievement, and \\
social behavior of 5 \\
D/HH students, 5 \\
D/HH students \\
with additional \\
disabilities \\
(D/HH-D), and 18 \\
nondisabled, \\
hearing peers in a \\
co-enrolled, Grade \\
$3-4-5$ combination \\
classroom \\
(n=28)
\end{tabular} & $\begin{array}{l}\text { Findings indicated that } \\
\text { differences did exist in } \\
\text { academic achievement } \\
\text { across disability type. } \\
\text { Students with D/HH } \\
\text { differed significantly from } \\
\text { their hearing peers in the } \\
\text { variables under study. }\end{array}$ & $\begin{array}{l}\text { Co-enrolment is a } \\
\text { possible model of } \\
\text { inclusion for D/HH } \\
\text { students. }\end{array}$ & $\begin{array}{l}\text { Positive impact of } \\
\text { inclusion of children } \\
\text { with hearing loss } \\
\text { Major impact of } \\
\text { inclusion setting }\end{array}$ \\
\hline 13. & $\begin{array}{l}\text { Theunissen et } \\
\text { al. (2014). }\end{array}$ & $\begin{array}{l}\text { This was a } \\
\text { retrospective, } \\
\text { multicenter study } \\
(\mathrm{n}=252)\end{array}$ & $\begin{array}{l}\text { Hearing-impaired children } \\
\text { experienced lower levels of } \\
\text { self-esteem than those with } \\
\text { no hearing impairment. }\end{array}$ & $\begin{array}{l}\text { Children with } \\
\text { hearing impairment } \\
\text { need adequate } \\
\text { support.to improve } \\
\text { their self-esteem. }\end{array}$ & $\begin{array}{l}\text { Enhancement of } \\
\text { self-esteem is } \\
\text { important for } \\
\text { children with } \\
\text { hearing impairment. } \\
\text { - Major impact of } \\
\text { inclusion setting }\end{array}$ \\
\hline 14. & $\begin{array}{l}\text { Alegre de la } \\
\text { Rosa, O. M. A.\& } \\
\text { Angulo, L. M. } \\
\text { V. (2019). }\end{array}$ & $\begin{array}{l}\text { This was a study } \\
\text { which made use of } \\
\text { exploratory factor } \\
\text { analysis to } \\
\text { determine the } \\
\text { reliability and } \\
\text { relevance of ICAQ }\end{array}$ & $\begin{array}{l}\text { The result indicates four } \\
\text { factors of students' attitudes } \\
\text { towards IE: Family } \\
\text { collaboration and utilize of } \\
\text { technology, inclusion of the } \\
\text { students in the centre, } \\
\text { communication with medical } \\
\text { professionals, and evaluation } \\
\text { of the supporting technology }\end{array}$ & $\begin{array}{l}\text { The students' } \\
\text { attitudes towards IE } \\
\text { was significant. The } \\
\text { scale (ICAQ) valid to } \\
\text { measure the attitudes } \\
\text { of students with } \\
\text { impairments towards } \\
\text { the inclusive setting. }\end{array}$ & $\begin{array}{l}\text { Major impact of } \\
\text { inclusion setting }\end{array}$ \\
\hline 15. & $\begin{array}{l}\text { Constantinescu- } \\
\text { Sharpe et al. } \\
\text { (2017). }\end{array}$ & $\begin{array}{l}\text { This is a study that } \\
\text { involves parents of } \\
\text { children with } \\
\text { hearing } \\
\text { impairment } \\
\text { between the age of } \\
4-5 \text { years who } \\
\text { learnt through LSL } \\
\text { approach } \\
(n=78) .\end{array}$ & $\begin{array}{l}\text { The majority of the children } \\
\text { with hearing loss are as well } \\
\text { equated in terms of outcomes } \\
\text { with those with typical } \\
\text { hearing in terms of } \\
\text { education, interaction with } \\
\text { society, and fulfilment of } \\
\text { social roles' aspects of social } \\
\text { inclusion. }\end{array}$ & $\begin{array}{l}\text { The use of LSL } \\
\text { approach in the } \\
\text { teaching of children } \\
\text { with hearing loss } \\
\text { may be beneficial. }\end{array}$ & $\begin{array}{l}\text { - Approach to } \\
\text { teaching needs to be } \\
\text { considered by } \\
\text { teachers when } \\
\text { teaching children } \\
\text { with hearing loss. } \\
\text { - Major impact of } \\
\text { inclusion setting }\end{array}$ \\
\hline 16. & $\begin{array}{l}\text { Rachel, E. } \\
(2012) .\end{array}$ & $\begin{array}{l}\text { This was a doctoral } \\
\text { thesis }\end{array}$ & $\begin{array}{l}\text { Findings indicated that } \\
\text { inclusion classrooms: } \\
\text { - Do not hurt a student's } \\
\text { self-esteem. } \\
\text { - Promote desired } \\
\text { behaviours and social } \\
\text { skills. }\end{array}$ & $\begin{array}{l}\text { ESE inclusion } \\
\text { practices are } \\
\text { effective. }\end{array}$ & $\begin{array}{l}\text { Positive impact of } \\
\text { inclusion of children } \\
\text { with hearing loss } \\
\text { Major impact of } \\
\text { inclusion setting }\end{array}$ \\
\hline
\end{tabular}

Two themes emerged from the systematic review; studies in which inclusion setting had a minor impact on deaf children and those in which inclusion setting had a major impact on deaf children. The two themes are discussed below. 
Theme 1: Minor Impact on Deaf Children $(n=4)$

Following the conduct of a systematic review of literature, four studies were found in which inclusion setting had a minor impact on academic performance, social participation, and students' self-assessment. These were studied by Ameye, Adeyemo, Eziyi, Amusa, Ogunniyi and Otoghile (2015); Eriks-Brophy and Whittingham (2013); Mapolisa and Tshabalala (2013) and Alasim (2018). These studies suggest that teacher education programs should be tailored to suit deaf children. Students with hearing impairment should be taught in a way that mitigates hindrances in general education classrooms. Further, these studies emphasize the use of appropriate pedagogical skills and the availability of resources for teachers so that they can manage hearing impaired children. Thus, there must be specific strategies for deaf and hard-of-hearing students to ensure their participation in classroom settings.

\section{Theme 2: Major Impact on Deaf and Hard-of-Hearing Children $(n=12)$}

Figure 2 presents the studies which displayed a major positive impact of inclusion setting on deaf and hard-of-hearing children. Nine of the studies (75\%) showed a positive impact of over $30 \%$.

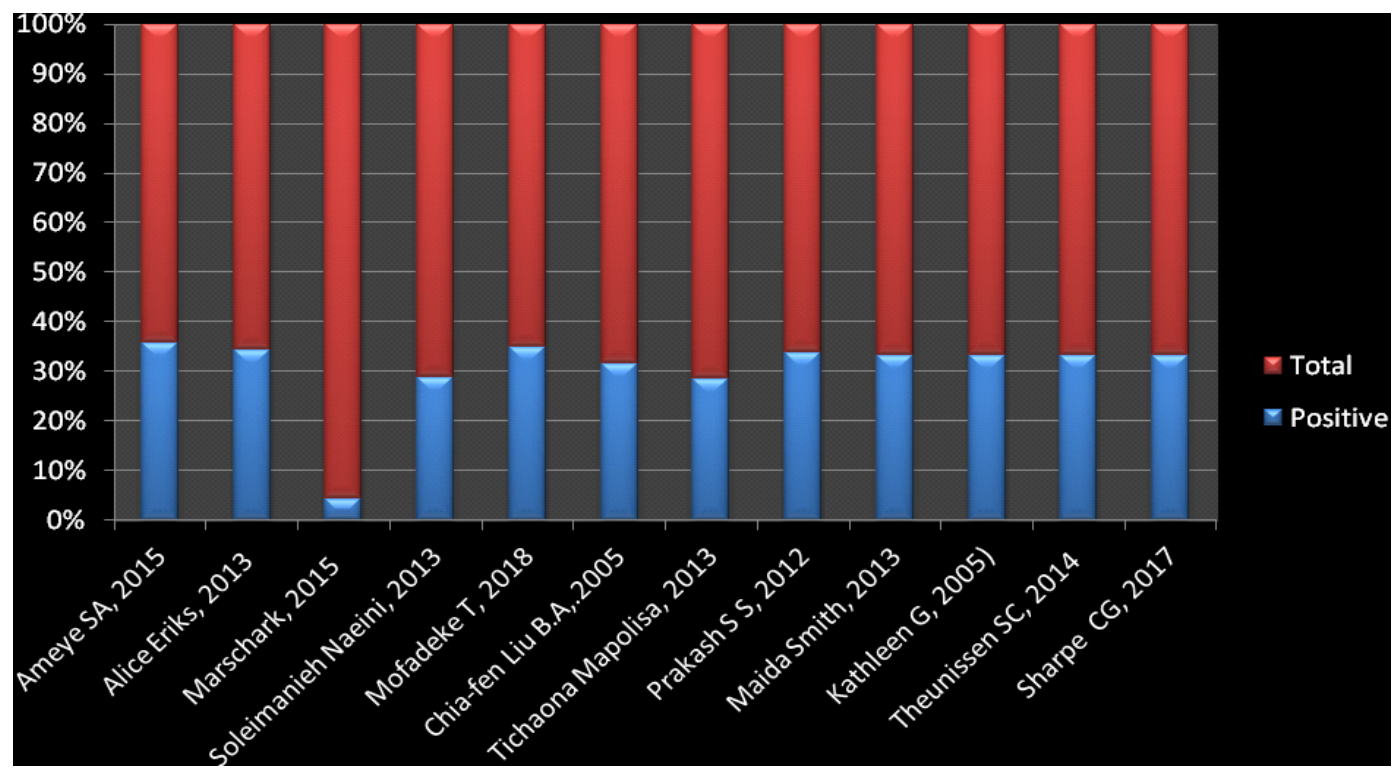

Figure 2: Studies with major impact of inclusion setting on hearing-impaired children

\subsection{Findings for Meta-Analysis}

Table 3 contains summary statistics of studies included in the meta-analysis. A total of 12 studies which were found to be eligible for meta-analysis had a mean sample size of 539.7 ( $95 \% \mathrm{CI}=-402$ to 1481.5$)$, Median value of 55.0 variance of $4974537.50(\mathrm{SD}=2230.3)$, SE Mean=455.2, Coff. of Skewness $=4.8(p<0.0001)$ and Coff. of Kurtosis=23.8 ( $p<0.0001)$. 
Table 3: Summary Statistics of Studies Included in meta-analysis.

\begin{tabular}{|l|l|} 
Statistic & Value \\
\hline Sample size & 24 \\
\hline Lowest value & 14.0 \\
\hline Highest value & 11000.0 \\
Arithmetic mean & 539.7 \\
\hline $95 \%$ CI for the Arithmetic mean & -402.0 to 1481.5 \\
\hline Median & 55.0 \\
\hline $95 \%$ CI for the median & 37.4 to 83.5 \\
Variance & 4974537.5 \\
\hline Standard deviation & 2230.3 \\
\hline Relative standard deviation & $4.1322(413.2 \%)$ \\
\hline Standard error of the mean & 455.2 \\
\hline Coefficient of Skewness & $4.8(p<0.0001)$ \\
Coefficient of Kurtosis & $23.8(p<0.0001)$ \\
\hline D'Agostino-Pearson test & Reject Normality \\
for Normal distribution & $(p<0.0001)$ \\
\hline
\end{tabular}

Figure 3 is a forest plot for the 12 studies. All the studies except that by Marschark et al. (2015) had similar effect sizes. Incidentally, the study by Marschark et al. (2015) was the most reliable in the meta-analysis yet it was the same study that exhibited the least impact of inclusion setting among the 12 studies that were in the major impact category. The least reliable was that Kathleen and McCain (2005).

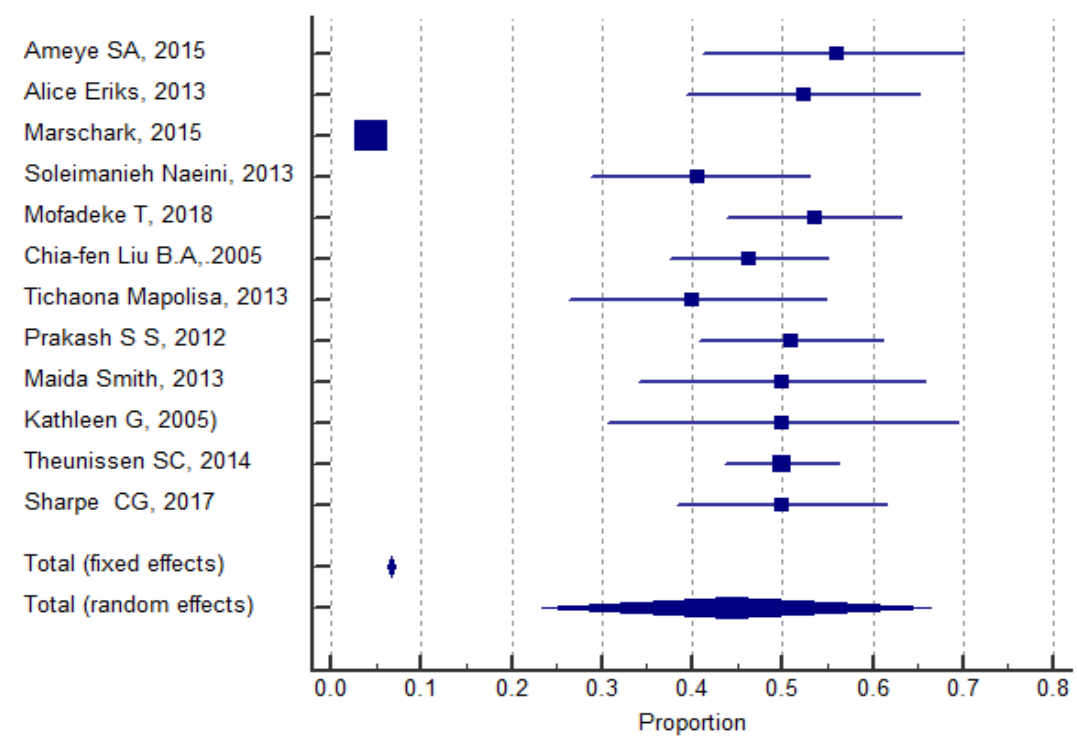

Figure 3: Forest Plot for the impact of inclusion setting on D/HH students ( $n=12)$

The relationship between effect sizes in the studies and their statistical power was assessed by examining the funnel plot (Fig. 4). The plot displays a huge asymmetry caused by eleven studies. This suggests the possible presence of publication bias which means that the outcome of the studies influenced the 
decision of whether to publish them or not. Such bias may be reduced by having journals publish high-quality studies on inclusion setting regardless of novelty or unexciting results, and by publishing protocols or full-study data sets.

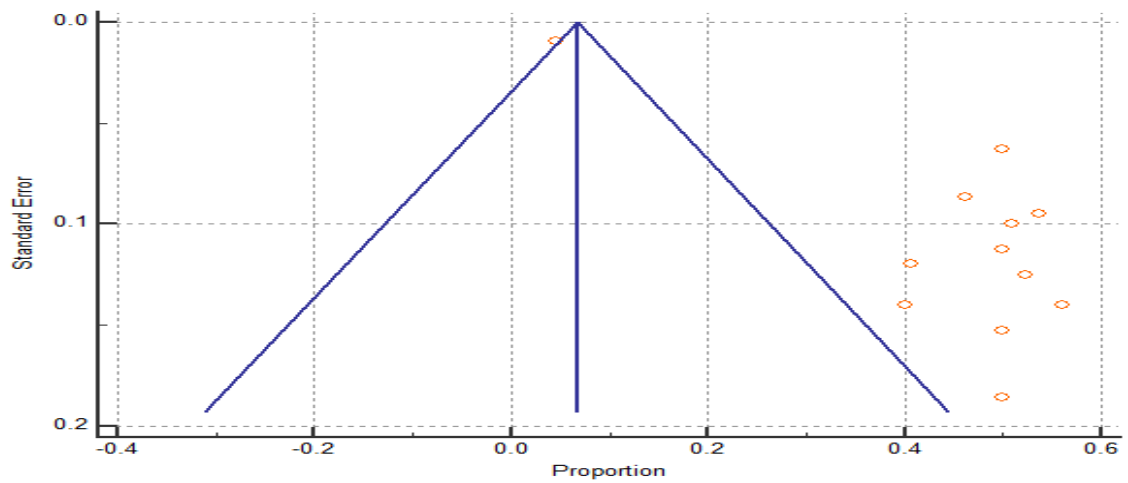

Figure 4: Funnel plot for the effect of inclusion setting on D/HH Students

The proportion for the total fixed effect was $6.6 \%$ and that of the total random effect was $44.3 \%$ (See Table 4 ). The combined value for $\mathrm{I}^{2}$ was $99 \%$ suggesting that there existed a high degree of heterogeneity across the studies included in the analysis $(p<0.0001)$.

Table 4: Effect of inclusion setting on D/HH students

\begin{tabular}{|c|c|c|c|c|c|}
\hline \multirow[t]{2}{*}{ Study } & \multirow[t]{2}{*}{ Sample size } & \multirow{2}{*}{$\begin{array}{l}\text { Proportion } \\
(\%)\end{array}$} & \multirow[t]{2}{*}{$95 \% \mathrm{CI}$} & \multicolumn{2}{|c|}{ Weight (\%) } \\
\hline & & & & Fixed & Random \\
\hline Ameye et al. (2015). & 50 & 56.0 & 41.2 to 70.0 & 0.4 & 8.2 \\
\hline $\begin{array}{l}\text { Eriks-Brophy \& } \\
\text { Whittingham (2013). }\end{array}$ & 63 & 52.3 & 39.4 to 65.1 & 0.5 & 8.3 \\
\hline $\begin{array}{l}\text { Marschark et al. } \\
\text { (2015). }\end{array}$ & 11000 & 4.5 & 4.1 to 4.9 & 91.7 & 8.5 \\
\hline $\begin{array}{l}\text { Soleimanieh et al. } \\
\text { (2013) }\end{array}$ & 69 & 40.5 & 28.9 to 53.0 & 0.5 & 8.3 \\
\hline $\begin{array}{l}\text { Jaiyeola \& Adeyemo } \\
\text { (2018) }\end{array}$ & 110 & 53.6 & 43.8 to 63.1 & 0.9 & 8.4 \\
\hline Chia-fen, L. (2013) & 132 & 46.2 & 37.5 to 55.0 & 1.1 & 8.4 \\
\hline $\begin{array}{l}\text { Mapolisa \& } \\
\text { Tshabalala (2013) }\end{array}$ & 50 & 40.0 & 26.4 to 54.8 & 0.4 & 8.2 \\
\hline Prakash, S. S. (2012) & 100 & 51.0 & 40.8 to 61.1 & 0.8 & 8.3 \\
\hline Maida, S. (2013) & 42 & 50.0 & 34.1 to 65.8 & 0.3 & 8.2 \\
\hline $\begin{array}{l}\text { Kathleen, G. \& } \\
\text { McCain, S. A. (2005) }\end{array}$ & 28 & 50.0 & 30.6 to 69.3 & 0.2 & 8.0 \\
\hline $\begin{array}{l}\text { Theunissen et al. } \\
\text { (2014) }\end{array}$ & 252 & 50.0 & 43.6 to 56.3 & 2.1 & 8.4 \\
\hline $\begin{array}{l}\text { Constantinescu- } \\
\text { Sharpe, C. G. (2017) }\end{array}$ & 78 & 50.0 & 38.4 to 61.5 & 0.6 & 8.35 \\
\hline Total (fixed effects) & 11974 & 6.6 & 6.2 to 7.1 & 100.0 & 100.0 \\
\hline $\begin{array}{l}\text { Total (random } \\
\text { effects) }\end{array}$ & 11974 & 44.3 & 23.4 to 66.3 & 100.0 & 100.0 \\
\hline
\end{tabular}




\section{Discussion}

Scientometric analysis in this research involved 16 studies. The studies were conducted in diverse countries using diverse research designs. When all these studies were further analysed through a systematic review, two themes emerged; which are the studies with minor and major impact.

Numerous studies (Ameye et al., 2015; Rachel, 2012) have systematically highlighted the key to the success of inclusion settings on $\mathrm{D} / \mathrm{HH}$ students. For instance, the role of trans-disciplinary intervention services (Mellon et al. 2009), facilitating staff's understanding of 'identity' (Bell et al., 2016), attending regular secondary schools, and the role of good spoken language (Marschark et al., 2015) in their ability and emotional well-being and studies on improving intervention (Solaimanih et al., 2013; Ameye et al., (2015). However, contrary to studies by Mapolisa and Tshabalala (2013) who conclude that there are no specific strategies in inclusion settings for deaf and hearing students. In addition, some studies also emphasize factors that encourage $\mathrm{D} / \mathrm{HH}$ students to have uncontrolled attention before a lecture (Warner-Czyz et al., 2015). Previous studies have suggested that attitudes of teachers toward disabled students in inclusive classrooms settings are highly significant and do influence these students with respect to the reporting of low loneliness, maintaining their self-esteem, and acceptance of peers (Luftig, 1985; Campbell, Dodson \& Bost, 1985). The study by Pavri and Luftig (2000) also indicated the urgent need for the preparation programs to be able to provide and address social support for students with disabilities in the general classroom. Therefore, it appears certain strategies are needed to facilitate social work for students in all educational settings. Therefore, it is imperative for students with learning disabilities to receive active and intentional coaching that could result in acceptance in learning social behaviour. Mellon et al. (2009) found that educational programs need to provide children with social-emotional learning, innovations for auditory perception, access to the full range of basic skills essential for social and academic achievements. Another study by Warner-Czyz et al. (2015) concluded that children with hearing disabilities were significantly more positive in global self-esteem ratings compared to hearing individuals $(t=2.38, p=.02)$. Similarly, they found significant positive correlations between self-esteem ratings with affiliation $(r=.42, p=.002)$. Consequently, it indicates an urgent need for professionals and clinicians working with children suffering from hearing loss to recognize components responsible for self-esteem. A study by Pujari and Annapurna (2015) in Indian primary schools on mental retardation cases also came with a similar conclusion of the need for an adequate support system for the success of inclusive education in different kinds of patients.

The findings of our systematic review are in line with previous research. For example, a systematic review by Warner-Czyz. et al. (2015) reported that children with hearing loss rated global self-esteem significantly more positively compared to hearing peers and a significant positive relationship was established between self-esteem ratings with both affiliation $(\mathrm{r}=.42, p=.002)$ and attention $(\mathrm{r}=.45, p$ $=.001$ ). Whereas, a significant negative relationship was established between global self-esteem and depressive mood in the present study $(\mathrm{r}=.60, p=.001)$. 
It was widely reported that self-esteem is highly significant for psychosocial functioning. Hypothetically, hearing-impaired (HI) children have lower levels of self-esteem, due to the frequent experience of lower language and communication skills (Theunissen, et al., 2014). The special education services legal and scientific basis was based on the positive outcomes for students with disabilities when exposed to inclusive versus segregated education (National Council on Disability, 2018). Experienced teachers do not have challenges to structure lessons in advance, however, planning in teaching inclusion classes is vital and considered a valuable procedure. To be specific, the procedure of how to figure out the best strategies to engage and accommodate students' challenges, physical needs, interests, developmental levels, and gifts that can help teachers in achieving realistic inclusion for all students (Willis, 2007)

Surprisingly, a few findings of our systematic review have displayed contradictory results as compared to prior studies by Ameye et al. (2015) and Alasim (2018) A A systematic review of literature by Yu-Han, Potměšil and Brenda (2014) identified two broad themes - including process and interactions - with peers and intervention programs. Studies have indicated that $\mathrm{D} / \mathrm{HH}$ children are liable to encounter difficulties in managing, initiating, and communicating with hearing-peers in an inclusive environment. For the social participation of $\mathrm{DHH}$ children, co-enrollment and social skills training programs were reported to be effective interconnections. The communication and social skills of D-HH children, children with general hearing reactions, and the influence of encyclopaedias are described as important features as far as social interactions are a concern. A study by Batten et al. (2014) also reveals that a wide range of factors are associated with social relationships between deaf and hearing children. A study by Antia et al. (2011) also reported that deaf and hearing children differed in social competence and that deaf children heard less on social and socially re-trained behaviour than hearing children. All these studies show the variability of the data in the literature, which is evident in our study. We can, therefore, conclude from our meta-analysis that overall the impact of inclusion setting is significant $(6.6 \%$ to $44.3 \%$ in the fixed and random effect models, respectively).

\section{Conclusion}

The combined proportion impact of 'inclusion setting' ranged from 6.6 percent (fixed effect) to 44.3 percent (random Effect) as per calculated effect sizes in metaanalysis. Data also displayed statistical significance $[\mathrm{p}<0.0001, \mathrm{Q}=1153.8,95 \% \mathrm{CI}$ for I2=98.8-99.9]. Thus, we can conclude from the findings of the present study that the inclusion setting improves academic performance, social interaction, and self-esteem of D/HH students. Furthermore, based on the outcomes of the present study, we recommend that there is a need to handle $\mathrm{D} / \mathrm{HH}$ students not only appropriately but also understand the fact that it is difficult for many such children to develop a language unless they have access to a 'good inclusion setting'. Therefore, practitioners and policymakers must advocate the need for devising special strategies for such children. Consequently, the inclusion of $\mathrm{D}-\mathrm{HH}$ children in mainstream classrooms needs to focus more on extensive research in 'inclusive education' in the future for better communication and social interaction of $\mathrm{D} / \mathrm{HH}$ students. 


\section{References}

Alasim, K. N. (2018). Participation and Interaction of Deaf and Hard-of-Hearing Students in Inclusion Classroom. International Journal of Special Education, 33(2), 1-14.

Alegre de la Rosa, O. M. A., \& Angulo, L. M. V. (2019). Attitudes of Children with Hearing Loss towards Public Inclusive Education. Education Sciences, 9(3), 244. https://doi:10.3390/educsci9030244

Allison, E. (2015). The Effects of Inclusion Classrooms on Students with and Without Developmental Disabilities: Teachers' Perspectives on the Social, Emotional, and Behavioral Development of All Students in Inclusion Classrooms. Graduate School of Professional Psychology: Doctoral Papers and Masters Projects, 31.

Ameye, S. A., Adeyemo, A., Eziyi, J., Amusa, Y., Ogunniyi, G., \& Otoghile, B. (2015). The psychosocial consequences of severe deafness and the modifying effect on the socioeconomic position in a special education institution setting: A pilot study. Journal of Indian Speech Language Hearing Association, 29, 8-11.

Antia, S. D., Jones, P., Luckner, J., Kreimeyer, K. H., \& Reed, S. (2011). Social Outcomes of Students Who are Deaf and Hard of Hearing in General Education Classrooms. Exceptional Children, 77(4), 489-504.

Batten, G., Oakes, P. M., \& Alexander, T. (2014). Factors associated with social interactions between deaf children and their hearing peers: a systematic literature review. Journal of deaf studies and deaf education,19(3), 285-302. https://doi.org/10.1093/deafed/ent052

Bell, D., Carl, A., \& Swart, E. (2016). Students with hearing impairment at a South African university: Self-identity and disclosure. African Journal of Disability, 5(1), 229. https://doi.org/10.4102/ajod.v5i1.229

Borders, C., Bock, S., Giese, K., Gardiner-Walsh, S., \& Probst, K. (2018). Interventions for Students Who Are Deaf/Hard of Hearing. In F. Obiakor \& J. Bakken (Eds.) Viewpoints on Interventions for Learners with Disabilities (Advances in Special Education) Vol. 33, pp. 75-105, Emerald Publishing Limited. https://doi.org/10.1108/S0270-401320180000033005

Callow-Heusser, C. A. (2011). The effects of early identification and intervention on language outcomes of children born with hearing loss. [Dissertation]. Utah State University.

Campbell, N. J., Dodson, J. E., \& Bost, J. M. (1985). Educator perceptions of behavior problems of mainstreamed students. Exceptional Children, 51,298- 303.

Campbell, S. M., Braspenning, J., Hutchinson, A., \& Marshall, M. N. (2003). Research methods used in developing and applying quality indicators in primary care. $B M$ J $\begin{array}{llll}\text { (Clinical research } & \text { ed.), 326(7393), }\end{array}$ https://doi.org/10.1136/bmj.326.7393.816

Chia-fen, L. (2013). Academic and social adjustment among deaf and hard of hearing college students in Taiwan (Dissertation). University of Kansas. Retrieved from https://goo.gl/yUT7vd

Constantinescu-Sharpe, G., Phillips, R. L., Davis, A., Dornan, D., \& Hogan, A. (2017) Social inclusion for children with hearing loss in listening and spoken Language early intervention: an exploratory study, BMC Pediatr, 17(1), 74. https:// doi.org/10.1186/s12887-017-0823-y

Dalton, C. (2011). Social-emotional Challenges Experienced by Students Who Function with Mild and Moderate Hearing Loss in Educational Settings. Exceptionality Education International, 21, 28-45. Retrieved from https://ir.lib.uwo.ca/eei/vol21/iss1/4

Davis, P., \& Florian, L. (2004). Teaching Strategies and Approaches for Pupils with Special Educational Needs: A Scoping Study. Report submitted to the universities of 
Manchester and Cambridge. Retrieved from https://dera.ioe.ac.uk/6059/1/RR516.pdf

Eriks-Brophy, A., \& Whittingham, J. (2013). Teachers' Perceptions of the Inclusion of Children with Hearing Loss in General Education Settings. American Annals of the Deaf, 158(1), 63-97.

Jaiyeola, M. T., \& Adeyemo, A. A. (2018). Quality of life of deaf and hard of hearing students in Ibadan metropolis, Nigeria. Plos one, 13(1). https://doi.org/10.1371/journal.pone.0190130

Kathleen, G., \& McCain, S. A. (2005). Academic and Social Status of Hearing, Deaf, and Hard of Hearing Students Participating in a Co-enrolled Classroom. Communication Disorders Quarterly, 27(1), 20-32.

King, N., \& Ryan, B. J. (2019). The Impact of Social Inclusion on the Social Development of Students with a General Learning Difficulty in Postprimary Education in Ireland. Education Research International, 2019, 7. https://doi.org/10.1155/2019/6327567

Liversidge, A. G. (2003). Academic And Social Integration Of Deaf And Hard-Of-Hearing Students (PhD Thesis). Carnegie Research-I University Liversidge.

Luftig, R. L. (1985). The reality of children's loneliness. Paper presented at the Annual Meeting of the American Educational Research Association, Chicago.

Mapolisa, T., \& Tshabalala, T. (2013). The impact of inclusion of children with hearing impairment into regular schools: A case study of Dakamela primary school in Zimbabwe, International Journal of Asian Social Science, 3(7), 1500-1510.

Marschark, M., Shaver, D. M., Nagle, K. M., \& Newman, L. A. (2015). Predicting the Academic Achievement of Deaf and Hard-of-Hearing Students from Individual, Household, Communication, and Educational Factors. Exceptional Children; 81(3), 350-369.

Mason, G., Williams, G., \& Cranmer, S. (2009). Employability skills initiatives in higher education: what effects do they have on graduate labour market outcomes?, Education Economics, 17(1), 1-30, https:/ / doi.org/10.1080/09645290802028315

Mellon, N. K., Ouellette, M., Greer, T., \& Gates-Ulanet, P. (2009). Achieving developmental synchrony in young children with hearing loss. Trends in amplification, 13(4), 223240. https://doi.org/10.1177/1084713809356701

National Council on Disability. (2018). The Segregation of Students with Disabilities. https://ncd.gov/sites/default/files/NCD_Segregation-SWD_508.pdf

National Research Council. (2004). Impact of Hearing Loss on Daily Life and the Workplace. In R. A. Dobie \& S. Van Hemel (eds.) Hearing Loss: Determining Eligibility for Social Security Benefits. Washington (DC): National Academies Press (US). Retrieved from https://www.ncbi.nlm.nih.gov/books/NBK207836/

Negeri, Z. F., Shaikh M., \& Beyene J. (2018). Bivariate random-effects meta-analysis models for diagnostic test accuracy studies using arcsine-based transformations. Biom J., 60(4), 827-844.

Pavri, S., \& Luftig, R. (2000). The Social Face of Inclusive Education: Are Students with Learning Disabilities Really Included in the Classroom? Journal of Preventing School Failure: Alternative Education for Children and Youth, 45(1), 8-14, https://doi.org/10.1080/10459880109599808

Prakash, S. S. (2012). Inclusion of Children with Hearing Impairment in Schools: A Survey on Teachers' Attitudes. Disability', CBR and Inclusive Development Journal, 23(3), 90111.

Preferred Reporting Items For Systematic Review \& Meta-Analysis (PRISMA). (2009). Retrieved from http://www.prisma-statement.org/ 
Pujari, J., \& Annapurna, M. (2015). A study on available support systems in inclusive setting for the students with mental retardation. Indian Journal of Cerebral Palsy, 1, $35-41$.

Rachel, E. (2012). Inclusion Classrooms as it Relates to Self-Esteem, Behavior, and Social Skills (PhD Thesis) Trampler Southeastern University - Lakeland.

Soleimanieh, N. T., Keshavarzi, A. F., Hatamizadeh, N., \& Bakhshi, E. (2013). The effect of social skills training on perceived competence of female adolescents with deafness. Iranian Red Crescent Medical Journal, 15(12):e5426. https://doi.org/10.5812/ircmj.5426

Sterne, J. A., \& Egger, M. (2001). Funnel Plots for Detecting Bias in Meta-Analysis: Guidelines on Choice of Axis. Journal of Clinical Epidemiology, 54(10), 1046-1055. https://doi.org/10.1016/s0895-4356(01)00377-8.

Theunissen, S. C., Rieffe, C., Netten, A. P., Briaire, J. J., Soede, W., Kouwenberg, M., \& Frijns, J. H. (2014). Self-esteem in hearing-impaired children: the influence of communication, education, and audiological characteristics. PloS one, 9(4), e94521. https://doi.org/10.1371/journal.pone.0094521

Warner-Czyz, A. D., Loy, B. A., Evans, C., Wetsel, A., \& Tobey, E. A. (2015). Self-esteem in children and adolescents with hearing loss. Trends in hearing, 19, 2331216515572615. https:// doi.org/10.1177/2331216515572615

WHO. (2020). Deafness and hearing loss 2020. Retrieved from https://www.who.int/news-room/fact-sheets/detail/deafness-and-hearingloss

Willis, J. (2007). Brain-friendly strategies for the inclusion classroom: Insights from a neurologist and classroom teacher. Alexandria, VA: Association for Supervision and Curriculum Development.

Yu-Han, X., Potměšil, M., \& Brenda, P. (2014). Theory/Review Children Who Are Deaf or Hard of Hearing in Inclusive Educational Settings: A Literature Review on Interactions with Peers. Journal of Deaf Studies and Deaf Education. 19, 4, 423-437. https://doi.org/10.1093/deafed/enu017 